Historia: Jurnal Program Studi Pendidikan Sejarah

Vol. 3 No. 2 (2018): 102-109

P-ISSN 2301-8305

E- ISSN 2599-0063

\title{
ADAT PERNIKAHAN SUKU BUGIS DI KELURAHAN TAGARAJA KECAMATAN KATEMAN SUNGAI GUNTUNG PROVINSI RIAU
}

\section{THIS STUDY DISCUSSES THE CUSTOMS OF BUGIS TRIBE MARRIAGE IN TAGARAJA VILLAGE, KETMAN SUB-DISTRICT, SUNGAI GUNTUNG, RIAU PROVINCE.}

\author{
Fitri Yanti ${ }^{1)}$, Darmayanti ${ }^{2)}$ \\ ${ }^{1}$ (Prodi Pendidikan sejarah, FKIP, Universitas Riau Kepulauan, Indonesia) \\ 2 (Prodi Pendidikan sejarah, FKIP, Universitas Riau Kepulauan, Indonesia) \\ ${ }^{1)}$ Fit.ugm@gmail.com ${ }^{2)}$ Darmayanti@gmail.com
}

\begin{abstract}
Abstrak
Tujuan dari penelitian ini adalah untuk menjelaskan lebih dalam pelaksanaan dan makna adat adat pernikahan suku bugis di kelurahan Tagaraja Kecamatan Keteman Sungai Guntung Provinsi Riau. Jenis penelitian ini adalah kualitatif dengan menggunakan metode deskriptif. Keseluruhan data tersebut diperoleh dari wawancara, observasi dan dokumentasi Hasil penelitian ini menjelaskan bahwa pelaksanaan adat pernikahan suku bugis di kelurahan Tagaraja Provinsi Riau dimulai dari beberapa tahapan dimulai dari aktifitas penjajakan (mamanu'manu), peminangan (madutta), mappassiseng mattapa, (menyebarkan undangan), mappasau bonting, assimorong (akad nikah), malam mappaci, Resepsi.
\end{abstract}

Kata kunci: Adat Pernikahan, Suku Bugis, Kelurahan Tagaraja

\section{Abstract}

The purpose of this study was to explain more deeply the implementation and meaning of the customs of Bugis tribal marriages in Tagaraja village, Keteman Sungai Guntung sub-district, Riau Province. This type of research is qualitative using descriptive methods. The entire data is obtained from interviews, observation and documentation. Data obtained through direct interviews or can be obtained with other data or documents. The results of this study explain that the implementation of Bugis wedding customs in Tagaraja village, Riau Province starts from several stages starting from exploration activities (mamanu'manu), peminangan (madutta), mappassiseng mattapa, (spreading invitations), mappasau bonting, assimorong (marriage contract), night mappaci, The results of this study explain that the implementation of Bugis wedding customs in Tagaraja village, Riau Province starts from several stages starting from exploration activities (mamanu'manu), peminangan (madutta), mappassiseng mattapa, (spreading invitations), mappasau bonting, assimorong (marriage contract) , night mappaci.

Keywords: Adat Marriage, Bugis Tribe, Tagaraja Sub-district 
Historia: Jurnal Program Studi Pendidikan Sejarah

Vol. 3 No. 2 (2018): 102-109

P-ISSN 2301-8305

E- ISSN 2599-0063

\section{PENDAHULUAN}

Indonesia adalah Negara Kepulauan yang memiliki berbagai macam suku bangsa yang masing-masing sukunya memiliki adat-istiadat, bahasa, kepercayaan, keyakinan dan kebiasaanya yang berbeda-beda. Bedasarkan pada kegiatan yang telah terjadi secara turun- temurun dan mendarah daging di masyarakat Indonesia, salah satunya adalah adat istiadat pernikahan suku Bugis di Sungai Guntung Kecamatan Kateman Kabupaten Indragiri Hilir merupakan bentuk budaya asli masyarakat Indonesia yang telah ada sejak dahulu hingga sampai sekarang (Aini, 2013: 1).

Sungai Guntung adalah sebuah Kecamatan di Kabupaten Indragiri hilir Provinsi Riau, yang berada di Riau Daratan, dan terletak di antara perbatasan Riau dan Kepulauan Riau. Sungai Guntung memiliki satu-satunya Kelurahan ialah Kelurahan Tagaraja. Kelurahan Tagaraja merupakan satu- satunnya kelurahan yang ada di Sungai Guntung. Masyarakat Kelurahan Tagaraja terkenal dengan sikap keramah tamahannya, hal ini dapat dibuktikan dengan mudahnya menerima pendatang untuk menetap disini, salah satu ialah ialah dengan menerima kedatangan Suku Bugis dan menetap di Sungai Guntung. Suku Bugis merupakan suku pendatang yang berasal dari Sulawesi yang sengaja merantau ke Sungai Guntung untuk merubah nasib.

Proses adat pernikahan Suku Bugis memiliki makna dan pesan tersendiri dalam adat istiadat pernikahan tersebut. Dalam adat pernikahan Suku Bugis sebelum bersanding kepelaminan mereka mengadakan ritual dalam upacara pernikahan yang mmenggunakan kain kemudian ditutup dengan tikar pandan. Acara ini berlangsung selama tiga hari berturut-turut. Sebelum tiga hari menjelang pernikahan pengantin menjalani perawatan tradisional seperti mandi uap dan nipis yang dinamakan dengan cemme pasih. Cemme pasih merupakan mandi tolak bala yang dilakukan untuk meminta perlindungan tuhan dari bahaya.

\section{Teori Interpretatif Clifford Geertz}

Geertz mendefinisikan kebudayaan merupakan hal yang semiotic dan kontektual, Geertz juga menawarkan cara menafsir simbol-simbol kebudayaan secara komplit (thick). Sebuah tafsiran dengan memaparkan konfigurasi atau sistem simbol-simbol bermakna secara mendalam dan menyeluruh. Mengingat bahwa simbol budaya adalah kendaraan pembawa makna. Sistem simbol yang tersedia dalam kehidupan umum masyarakat yang sesunguhnya menunjukkan 
Historia: Jurnal Program Studi Pendidikan Sejarah

Vol. 3 No. 2 (2018): 102-109

P-ISSN 2301-8305

E- ISSN 2599-0063

system makna (system of meaning) bagaimana para warga masyarakat yang bersangkutan (Geertz: 1992: 1) antara lain:

1. Melihat, merasa, berpikir tentang dunia (sistem gagasan)

2. Bertindak berdasarkan nilai-nilai yang sesuai (sistem tindakan)

3. Akhirnya memanifestasikan diri dalam bentuk-bentuk benda kebudayaan.

\section{Adat istiadat}

Adat dapat dipahami sebagai tradisi lokal (local castom) yang mengatur intraksi masyarakat. Dalam ensiklopedi disebutkan bahwa adat adalah kebiasaan atau tradisi masyarkat yang telah dilakukan berulang kali secara turun temurun. Kata adat disini lazim dipakai tanpa membedakan mana yang mempunyai saksi seperti hukum adat dan mana yang tidak mempunyai sanksi seperti disebut adat saja. Menurut khazanah bahasa Indonesia tradisi segala sesuatu seperti adat, kebiasaan, ajaran, dan sebagainya yang turun temurun dari nenek moyang (Astuti, 2011: 32)

\section{METODOLOGI}

Jenis penelitian ini adalah kualitatif dengan menggunakan metode deskriptif. Penelitian kualitatif adalah jenis penelitian yang menghasilkan penemuan-penemuan yang tidak dapat dicapai dengan menggunakan prosedur-prosedur statistik atau cara-cara lain dari kuantifikasi (pengukuran). Penelitian kualitatif secara umum dapat digunakan untuk penelitian tentang kehidupan masyarakat, sejarah, tingkah laku, fungsionalisasi organisasi. Aktivitas sosial, dan lain-lain. Metode sejarah dapat diartikan sebagai metode penelitian dan penulisan sejarah dengan menggunakan cara, prosedur atau teknik yang sistematik sesuai dengan asas-asas adan aturan ilmu sejarah. Metode sejarah terdiri dari heuristik, kritik sumber, interprestasi dan historiografi (Daliman, 2015: 28).

Pada penelitian ini peneliti akan mengumpulkan data mengenai adat pernikahan Suku Bugis di Keluarahan Tagaraja Sungai Guntung Kecamatan Katema. Sumber penelitian sejarah terbagi atas dua jenis yaitu sumber primer dan sumber sekunder. Berikut ini uraian mengenai sumber primer dan sekunder dapat di bedakan atas: 
Historia: Jurnal Program Studi Pendidikan Sejarah

Vol. 3 No. 2 (2018): 102-109

P-ISSN 2301-8305

E- ISSN 2599-0063

Sumber sejarah primer adalah sumber sejarah yang direkam dan dilaporkan oleh para saksi mata (eyewitness). Data-data dicatat dan dilaporkan oleh pengamat atau partisipan yang benar-benar mengalami dan menyaksikan suatu peristiwa sejarah. Sumber primer ini dapat berupa kesaksian langsung dari pelaku sejarah (sumber lisan). Dokumen-dokumen, naskah perjanjian, arisip, (sumber tertulis), dan benda-benda arkeologi (sumber benda) (Daliman, 2015: $55)$.

Sumber data sekunder merupakan sumber data penelitian yang diperoleh penelitian secara tidak langsung melalui media prantara (yang diperoleh dan dicatat oleh pihak lain). Penulisan sumber sekunder bukanlah orang yang hadir dan menyaksikan sendiri suatu peristiwa, ia melaporkan apa yang terjadi berdasarkan kesaksian orang lain (Daliman 2015: 55). Observasi dalam kamus besar bahasa Indonesia berarti pengamatan atau peninjauan secara cermat. Sedangkan para ahli memberikan pemahaman observasi. Nasution (Dalam Satori 2003:56) mengungkapkan bahwa, observasi adalah dasar semua ilmu pengatauan data, yaitu fakta mengenai dunia kenyataan yang diperoleh melalui observasi.

Pengertian wawancara yang dikemukakan oleh Berg (dalam Satori, 2012: 130) membatasi wawancara seb+agai suatu percakapan dengan suatu tujuan, khususnya tujuan untuk mengumpulkan informasi. Wawancara adalah suatu teknik pengumpulan data untuk mendapatkan informasi yang digali dari sumber data langsung melalui percakapan atau Tanya jawab. Wawancara dalam penelitian kualitatif mendalam karena ingin mengeksplorasi informasi secara holistik dan jelas dari informan.

Dokumentasi merupakan rekaman kejadian masa lalu yang ditulis atau dicetak, dapat berupa catatan anecdotal, surat, buku harian dan dokumen-dokumen. Dokumen merupakan catatan peristiwa yang sudah berlalu. Dokumen bisa berbentuk tulisan, gambar, atau karya-karya monumental dari seseorang. Dokumen berbentuk yang tulisan misalnya catatan harian, sejarah kehidupan (life historis), criteria, biografi, peraturan, kebijakan. Studi dokumen merupakan pelengkap dari penggunaan metode observasi dan wawancara dalam penlitian kualitatif (Satori, 2012: 147). 
Historia: Jurnal Program Studi Pendidikan Sejarah

Vol. 3 No. 2 (2018): 102-109

P-ISSN 2301-8305

E- ISSN 2599-0063

\section{PEMBAHASAN}

Kedatangan Suku Bugis di Sungai Guntung terjadi $\pm 1960-1964$ dan juga suku Bugis dikenal dengan sifat perantauan. Sejak zaman dahulu, orang bugis memang sudah kental dengan sifat perantauan, mereka terkenal punya semangat juang dan semangat hidup yang lebih besar. Begitu juga dengan suku bugis yang ada di Sungai guntung mereka juga terkenal dengan semagat juang dan semangat hidup yang besar. Mereka datang ke sungai guntung di karenakan di kampung mereka susah mata pencarian dan lapangan pekerjaan terlalu sedikit dan menurut mereka di sungai guntung ini tempat yang tepat untuk berkebun dan berdagang awalnya orang bugis datang ke Sungai guntung sekitar tahun 1960an awalnya mereka datang ke Sungai Guntung mengunakan jalan laut dengan menggunakan perahu layar. Mereka mulai menginjakkan kaki di Sungai Guntung secara berbondong-bondong, mereka juga mampu hidup damai dengan masyarakat setempat dan sampai sekarang pun suku bugis masih banyak yang berdatangan di Sungai Guntung.

Sejak kedatangan Suku bugis di Sungai Guntung disinilah mereka memulai adat pernikahan mereka yang mereka bawa dari kampung halaman mereka walaupun sedikit terjadi perubahan dalam pernikahan di karenakan mereka sedikit mengikuti adat pernikahan penduduk asli yang ada di Sungai Guntung, tetapi tidak semua adat mereka tinggalkan bukan saja adat pernikahan melaikan bahasa daerah nya juga sedikit berubah yang semula bahasa kental dengan bahasa bugis kini tidak kental lagi karena di Sungai Guntung kental akan bahasa melayunya dan oleh sebab itu generasi-generasi baru banyak yang tidak mengerti akan bahasa bugis. Adapun tujuan Suku Bugis datang ke Sungai Guntung ialah untuk mecari rezeki, seperti berkebun berdagang dan lain-lain. Prosesi pernikahan adat Suku Bugis di kelurahan Tagaraja melewati beberapa tahap tertentu.

\section{Penjajakan (Маттапи' тапи')}

Маттапи' adalah proses lamaran atau merisik (dalam bahasa melayu). Dalam adat lamaran suku bugis proses mammanu' (merisik) di bagi menjadi dua proses sebagai berikut. Proses lamaran tidak resmi ini adalah pihak laki-laki menanyakan salah seorang gadis yang ingin dilamar dengan cara mermusyawarah antara pihak keluarga laki-laki dan keluarga perempuan isi 
Historia: Jurnal Program Studi Pendidikan Sejarah

Vol. 3 No. 2 (2018): 102-109

P-ISSN 2301-8305

E- ISSN 2599-0063

dari lamaran tersebut ialah menanyakan apakah gadis tersebut sudah memiliki tunangan atau belum.

Lamaran Resmi Proses yang kedua ini barulah keluarga pihak laki-laki membawa oleholeh sebanyak-banyaknya dalam hal ini pihak laki-laki berapa mahar yang harus di serahkan dan berapa pikul beras yang harus di bawa berasa kilo putul yang harus di bawa. Madduta adalah proses musyawarah antar dua keluarga besar untuk membicarakan segala hal yang terkait dengan rencana pernikahan. Sebelum pihak calon mempelai laki-laki datang ke rumah calon mempelai wanita, terlebih dahulu disepakati waktu peminangan tersebut Peminangan (Madduta) Mappasau bontting ( Merawat pengantin) Setelah selesai menyebarkan undangan pernikahan pernikahan adalagi ritual awal dalam upacara pernikahan. Acara ini di laksanakan selama tiga hari berturutturut. Sebelum hari $\mathrm{H}$ berlangsung selama tiga hari tersebut biasanya suku Bugis mengadakan perawatan tradisional untuk pengantin seperti mandi uap (bertangas).

Assimorong (Akad nikah) Akad nikah biasanya dilakukan di lokasi pempelai wanita. Bersama rombongan dengan membawa erang-erang (serba satu) erang-erang atau serba satu. Alat yang dibawa mempelai laki-laki berupa kue-kue tradisional orang bugis alat keperluan sehari-hari seperti kosmetik, sandal, tas, seperangkat alat sholat, baju, dan buah-buahan. Malam mapacci (malam berinai) Malam berinai adalah malam sesudah akad nikah berlangsung. Di malam ini biasanya di adakan khataman al-Quraan dan juga al-berzanji, pada acara ini biasanya di sediakan makanan-makanan bugis dan bunga telur untuk untuk diberikan kepada keluarga yang telah memberikan inai doa restu kepada kedua mempelai.

Resepsi adalah hari besar pernikahan antara kedua mempelai di hari besar inilah biasa keluarga mempelai memakai baju adat pernikahan suku bugis yang dikenal dengan baju bodo (tokko) bau tokko melambangkan sebagai identitas khas Suku Bugis. Sedangkan memakai kain samarinda berwarna merah melambangkan energi, api, dan gairah. Kemudian di samping baju boddo tersebut diletakkan sebuah keris dipinggang mempelai laki-laki hal ini mempunyai makna sebagai senjata yang bermaksud sebagai ilmu. Maksudnya seorang mempelai laki-laki tersebut harus mempunyai bekal senjata dan bekal ilmu yang cukup untuk menghadapi tantangan yang akan dijalani setelah pernikahan. 
Historia: Jurnal Program Studi Pendidikan Sejarah

Vol. 3 No. 2 (2018): 102-109

P-ISSN 2301-8305

E- ISSN 2599-0063

\section{KESIMPULAN DAN SARAN}

Berdasarkan hasil penelitian tentang adat pernikahan Suku Bugis di Kelurahan Tagaraja maka penulis dapat menyimpulkan:

1. Proses pelaksanaan adat pernikahan Suku Bugis di Kelurahan Tagaraja sampai sekarang masih tetap dilakukan walaupun sedikit berbeda dengan tempat asli mereka. Terdapat beberapa tahapan-tahapan tertentu dalam adat pernikahan Suku Bugis di Kelurahan Tagaraja, tahapan pertama yaitu penjajakan (mamanu'manu'), tahapan kedua yaitu peminangan (madutta), tahapan ketiga yaitu mappasisseng dan mattapa (menyebarkan undangan), tahapan keempat yaitu assimorong (akad nikah), tahapan kelima yaitu mappasau bonting (merawat pengantin), tahapan keenam yaitu malam mappaci (malam berinai), tahapan ketujuh yaitu resepsi.

2. Setiap proses atau tahapan pelaksanaan adat pernikahan Suku Bugis terdapat nilai, simbol dan makna tersendiri seperti Baju adat pernikahan Suku Bugis (baju boddo) melambangkan sebagai identitas pakaian khas Suku Bugis. Tabur beras dan kunyit maknanya sebagai penghormatan kepada mempelai laki-laki dan kue merah maknanya adalah sebagai pemanis. pancis dan rokok mengandung makna sebagai pembuka bicara, cincin melambangkan sebuah tanda jadi maknanya sebagai tanda sah atau diterimanya. 
Historia: Jurnal Program Studi Pendidikan Sejarah

Vol. 3 No. 2 (2018): 102-109

P-ISSN 2301-8305

E- ISSN 2599-0063

\section{REFERENSI}

Daliman. 2015. Metode Penelitian Sejarah. Yogyakarta: Ombak.

Geertz Clifford. 1992. Tafsir Kebudayaan. Yogyakarta. Penerbit: Kanisius.

Satori. Djam'an. 2012. Metodologi Penelitian Kualitatif. Bandung. Anggota Ikatan Penerbit Indonesia (IKAPI).

\section{Penelitian:}

Ainani Ahmad. 2010. Itsbat Nikah dalam Hukum Perkawinan di Indonesia. Jurnal Darussalam, Vol 10, No 2.

Astuti. 2011. Adat Pernikahan Suku Bugis di Sulawesi. Skripsi. Tidak Diterbitkan. Makassar: UIN Alauddin Makassar. 